\title{
Delay in payment effects on productivity of small and medium construction companies in Oman: exploration and ranking
}

\author{
Mubarak Al Alawi ${ }^{1}$ iD
}

Received: 28 March 2021 / Accepted: 10 August 2021 / Published online: 21 August 2021

(c) The Author(s) 2021

\begin{abstract}
Maintaining a stable productivity rate in a construction project is a challenge. Many external and internal factors influence it. Delay in payment is one of the factors representing the project cash flow and mirrors the company's financial stability status. This study explores the delay in payments effects on the construction productivity of the small and medium construction companies in Oman. Also, it ranks the delay in payment among other productivity factors. Sixty-five small and medium construction companies registered in Oman Tender Board participated in the questionnaire survey. The results showed that delay in payment significantly affects the financial stability of the companies. The delay in payment was ranked third out of 21 influencing productivity factors. The results were compared with a previous study that covered large construction companies in Oman. It was found that the rank of delay in payment in the small and medium construction is significantly higher than what was found in large companies.
\end{abstract}

Keywords Productivity $\cdot$ Construction $\cdot$ RII $\cdot$ Oman $\cdot$ Financial stability $\cdot$ Delay in payment

\section{Introduction}

Construction crew productivity contributes to the project's successfulness in terms of preserving and effectively utilizing the allocated time and budget. Different factors hinder the construction crew productivity, such as work environment, project nature, project resources, and project management (Florez et al., 2020; Kaveh \& Vazirinia, 2020; Park, 2006). It was found that the external work environment factors such as the inadequate supply of materials and the internal work environment factors such as the labors' negative attitude toward work lower the workforce productivity (Evanov et al., 2020; Taiwo, 2010). Working in a confined space with limited access to the site are examples of the effect of project nature on labor productivity (Jarkas \& Bitar, 2012). Weather also can negatively affect labors productivity. Extreme temperatures can reduce work hours (Al Balushi et al., 2020). It is also essential for the construction project to have a robust management system and an efficient communication protocol. Maintaining such requirement

Mubarak Al Alawi

alawim@squ.edu.om

1 Department of Civil and Architectural Engineering, Sultan Qaboos University, Al-Khod, 123 Muscat, Oman improves productivity (Chih et al., 2017). Advancement in construction technologies to improve construction productivity is continuously evolving; however, still, the construction industry suffers from the low productivity because of the large number of low-skilled laborers it host (Wong et al., 2020) and the low investment in research and development; especially, in the construction, building, and housing industry (Goodrum et al., 2009).

The losses in construction productivity have different effects in different areas in construction. For example, low productivity increases the project duration and forces the contractor to employ more crews to meet the project duration requirements (Halligan et al., 1994). Project cost will increase consequently, and the contractor's profit margin might negatively be affected. Besides, the quality of work can be affected by the crowdedness of the workforce in the project (Bajjou \& Chafi, 2020). The project supervisors may jeopardize project quality by softening the project control to get the work done. Sometimes long working duration is employed to compliment the losses in productivity during the standard working hours but extended working hours have physical, mental 2020and emotional physiological effects (United State Department of Labor, 2020). It can result in accidents causing injuries and sometimes death (Seo et al., 2015). Those effects described stems from the fact to 
maintain the plan construction output using the budgeted input; knowing that the productivity is defined as "a ratio of a volume measure of outputs to a volume measure of input use" (OCED, 2001). Thus, construction productivity is centered upon the performance of the resource. The construction company needs to identify the most influencing productivity factors to design proactive approaches to tackle productivity challenges during construction.

Construction productivity factors have schemed into different levels in construction projects. Some of many are related to the management, communication, and financial stability of the contractor. Shan et al., (2011) studied the relationship between different management programs and mechanical construction productivity. The study examined the pre-planning, team building, alignment, materials management, information automation, constructability and safety policies programs on mechanical productivity. The findings showed that projects with a high level of implementation of the studied programs experienced $40 \%$ better labor productivity. Doloi (2008) investigated the factors that influence productivity and found that planning and programming is the most significant influencer on productivity. In the context of communication, Alinaitwe et al., (2010) found that poor communication and lack of robust communication methods in construction influences labor productivity. Improving communication method definitely will enhance productivity, especially in the area of data flow management. Chalhoub and Ayer (2018) found that using mixed reality to communicate BIM content to onsite personnel in 3D enabled a significantly higher productivity rate, reduced the time to understand the design, and led to fewer errors. Furthermore, financial stability in terms of maintaining as planned cash flow influences construction productivity. For example, late issuance of progress payments affects workers and suppliers' payment and, after that, causes adverse effects on workers' motivation and contractors' creditability to suppliers' (Abdul Kadir et al., 2005).

Construction productivity being a significant contributor to the successfulness of a project, different researches were conducted to identify and rank the most productivity-sensitive factors. The contribution of productivity-related studies was to pinpoint productivity's challenging aspects and allow technological, management, and policy advancements to occur in the construction industry. Hasan et al. (Hasan et al., 2018) conducted a 30-year systematic review of literature about factors affecting construction productivity. A reasonable consensus exists on a few factors: non-availability of materials, inadequate supervision, skill shortage, lack of proper tools and equipment and incomplete drawings and specifications. It was also found that traditional construction projects remained the main focus.

Despite many types of research have been conducted in the area of the identification of productivity factors in the construction industry but almost little to none of the studies emphasized the small and medium construction companies, especially in Oman; the rank of most influencing factors might be correlated with the grade level of the construction company. Financial stability in terms of small and medium construction companies' cash flow may control productivity factors. Many of these companies are constructing multiple projects and rely on one project's cash flow to finance the other. Therefore, this study aims to answer two questions: (1) does the financial stability factor of the small and medium construction companies affect construction productivity? And (2) where this factor lies among the other productivity factors? The most recent study in Oman conducted their research in the first and excellent grades construction companies (Jarkas et al., 2015). It is possible to collect data from the excellent and first grades construction companies because of those companies' good establishments and the ability to communicate with them. It was found that delay in payment ranked 18 out of 33 productivity determinants. It is initially expected, and as a hypothesis, the rank of delay in payments is higher in small and medium construction companies.

The study starts by first conducting a literature review to highlight the regional advancement in this research area and identify the rank of construction productivity factors. The second part of the study is conducting a questionnaire survey. The questionnaire survey has two parts. The first part covers the respondents' perception of the effects of delay in payment on construction productivity. The second part ranks the relative importance of the construction productivity factors from the small and medium construction companies' perspectives.

\section{Background}

Comprehensive literature in the area of identification of productivity factors has been previously conducted. For example, besides Hasan et al., (2018) work, Naoum (2016) analyzed 119 productivity articles published in a time range between 1970 and 2014. However, this study will shed light on the advancement in this research in Oman and the near construction industries, focusing on how was financial stability considered. The purpose is to identify the most influencing productivity factors in the region and to use them to prepare the questionnaire survey.

El-Gohary and Aziz (2014) identified, investigated, and ranked factors that affect construction labor productivity in Egypt. The questionnaire survey targeted 300 of the top grades contractors in Egypt, and the collected data were categorized into three categories, management, human, and industry. It was found that the laborer experience, incentive programs, material availability, leadership, and efficient 
supervision are the most influencing productivity factors. The financial stability was not considered a productivity determinant because the surveyed companies are registered in the Egyptian Federation for Construction, and Building Contractors (EFCBC) and the financial stability in terms of the company's capital and income are primary criteria for consideration by the EFCBC.

Hiyassat et al., (2016) surveyed 100 engineers and 100 supervisors working for contractors in Amman, Jordan's capital. It was found that proper planning, worker-management relationship, education and experience, climate, and technology are the main productivity factors. One of the studied aspects was related to the relationship between financial stability and productivity. It was found that productivity is positively correlated with the company's financial strength. This fact is aligned with Shurrab (2018) findings. Shurrab (2018) evaluated the effect of motivational dimensions on the construction project managers in Jordan, and it was found that the good wage level is the top productivity motivator. Paying on time was the second motivational factor as per Al-Abbadi and Agyekum-Mensah (2019) findings in Jordan. Maintaining the construction company's financial stability is essential to provide a reasonable wage level and it a driver to improve productivity (Sweis et al., 2014); however, it was ranked last among the most influencing productivity factors in Jordan.

Productivity factors in Palestine construction industry were introduced by Mahamid (2013). Mahamid (2013) surveyed 59 contractors to identify the factors affecting labor productivity in building construction. The factors were grouped into managerial, financial, materials and equipment, environmental, and labor. It was seen that the financial stability was considered as a category and it was found that the financial status of the owner, the financial position of the contractor, and low wages are the most influencing ones. Those factors were ranked as the first, eleventh, and seventeenth, respectively, in the productivity factors' overall ranking. Moreover, these findings align with Shurrab (2018) and Al-Abbadi and Agyekum-Mensah (2019) results. Also, Enshaasi (2014) studied the constrains to Palestinian construction craftsmen productivity. Enshaasi (2014) surveyed 110 construction craftsmen. It was found that the lack of materials, safety, delay in payment, inspections delays, and low wages are the most influencing factors.

Khaleel and Nasser (2017) study was to identify and analyze productivity factors in the Iraqi construction industry. Khaleel and Nasser (2017) collected 42 productivity factors and grouped them into nine categories. The motivation group hosted a financial trace, and it was found that the delay in payment was ranked first among the most influencing productivity factors in the group. Also, Al-Rubaye and Mahjoob (2020a) investigated the factors affecting the productivity of construction labors in Iraq. Al-Rubaye and Mahjoob (2020a) conducted multiple Delphi rounds with
24 experts in construction. It was found that the financial status of the contractor and delay in payment are the top factors within the economic and financial productivity group. Al-Rubaye and Mahjoob (2020b) used the measured mile method to quantify the loss of labor productivity in the Iraqi construction industry and found that the management of the construction site, lack of communication and coordination, inadequate work schedule, floods, size of the project, size and schedule of the crew, and type of equipment were the main factors.

In the context of the Iranian construction industry, Ghoddousi et al., (2015) surveyed construction companies in category Grade 1 and Grade 2. Those companies represented the top construction companies in the Iranian construction industry. It was found that the amount of remuneration, timelines of remuneration, and incentive payments, which are related to the financial stability of the construction companies, are ranked first, fifth, and seventh, respectively. A recent study by Rad and Kim (2018) showed consistency in the findings when compared to Ghoddousi et al., (2015); it was found that the delay in payment was a dominant productivity factor. Furthermore, Jamshidi and Hatefi (2016) found that the changes in provisions and errors in design were major reasons for claims by contractors.

Jarkas and Bitar (2012) collected data from construction companies classified under the first, second, and third categories to identify factors affecting the construction labor productivity in Kuwait. The accumulated number of samples was 157 . It was found that the clarity of technical specifications, extent of change orders, coordination level during execution, the complexity of the design, and lack of supervision was the top five productivity factors. The delay in payment was ranked 29 out of 45 productivity factors. This result shows that the leading construction companies in Kuwait are financially stable. A similar study was conducted by Jarkas and Radosavljevic (2013); however, the research scope was to identify the motivational factors impacting the productivity of construction master craftsmen in Kuwait. It was found that the payment delay was the most influencing productivity factor. Similar results were found in the UAE's construction industry (Ailabouni et al., 2009); it was ranked third. Almathami et al., (2017) studied the factors influencing productivity in construction in Saudi Arabia. It was concluded that financial barriers are the most influencing productivity factor in the Saudi Arabia construction industry. Almathami et al., (2017) highlighted that financial obstacles are widely spread in lower grades construction companies. This finding is generally aligned with this research direction: the financial stability in terms of cash flow of the small and medium construction companies may influence the rank of productivity factors. Meanwhile, in the Bahrain construction industry, the delay in the payment factor's financial stability was ranked eleventh out of 37 productivity factor (Jarkas, 2015). 
In Qatar construction industry, it was found labor skill, shortage in material, supervision, lack of experienced labor, and communication are the most influencing productivity factors (Jarkas et al., 2012). Jarkas et al., (2012) found that payment delay was ranked twentieth out of 28 productivity factors. It is noticed that workers' motivation ranked higher than the delay in payment; however, it is known and previously mentioned that the delay in payment is the driver of motivational productivity factor. This fact is supported by Jarkas et al., (2014) findings. Jarkas et al., (2014) found lack of financial incentive schemes is the most de-motivational factor influencing the productivity of construction project managers in Qatar. The financial stability of the construction company affects the productivity of different levels of employees.

Yemen is recently known for unstable political and security conditions. Thus, the availability of the material in the market and the political and security stability are the most influencing productivity factors in Yemen construction industry (Alaghbari et al., 2018). In the context of Oman construction industry, Jarkas et al., (2015) investigated productivity factors affecting labor productivity in Omani construction companies. Jarkas et al., (2015) relied on data collected from excellent and firstgrade construction companies. It was found that errors and omissions in design drawings, change orders, communication, supervision and clarity of project specifications are the most influencing productivity factors in Oman construction companies. Furthermore, payment in delay was ranked eighteenth out of 33 productivity factors.

From the literature review, it is noticeable that most of the studies followed the same approach. It starts with identifying productivity groups, identifying the expected influencing productivity factors for each group, conducting a questionnaire survey to understand the respondents' perception of productivity factors and rank them based on their relative importance. Also, the studies were either labor or organizational focus. Furthermore, the collected data represents the industry's top construction companies, especially in research conducted in the Gulf Cooperation Council countries. The reason why is related to the accessibility of data and, intuitively, it is difficult to collect data from lower grades construction companies because of the large sample size required to generalize the results and because of the challenges associated with the communication with those companies. Moreover, it is expected that lower companies' financial stability may influence the ranking of productivity factors. This study motive is to survey the lower grades construction companies in Oman to identify their productivity influencing factors and know how those companies' financial stability changes the rank of the productivity factors.

\section{Financial stability and cash flow in construction}

Financial stability is defined as "episodes in which a large number of parties, whether they are households, companies or (individual) governments, experience financial crises which are not warranted by their previous behavior, and where these crises collectively have seriously adverse macro-economic effects" (Allen \& Wood, 2006). The definition stems from the consideration that financial stability is a microeconomic phenomenon studying how the economy behaves. It is well known that stability means the ability to resist changes and fluctuations or to the ability to absorbs external shocks or vibrations-author perception on stability. A Construction project is a system and poses stability characteristics. Volkov and Shilova (2016) investigated the definition of project stability and found that the stable state of the project as "the state of building or structure, the functional and engineering characteristics of which correspond to the feasible area and the dynamics of their changes does not assume any discrepancies within a certain period". Volkov and Shilova (2016) empathized on considering engineering safety and functional stability as the only factors to project stability, but the financial stability is also a significant contributor.

The financial stability has always been one of many performance indicators for the contractors. It is used in the contractors' prequalification process. The essential criteria of contractor evaluation are financial standing (includes financial stability, turnover, profit and obligations, and owned financial funds), technical ability, management capability, health and safety, and reputations (El-khalek et al., 2019; Plebankiewicz, 2009). The cash flow plays a critical role in the financial stability of the construction company. Many experienced failures because of the lack of cash flow to cover the operational expenses, rather than lack of efficient management (Huang et al., 2014; Kishore et al., 2011; Park et al., 2005). Kishore et al., (2011) mentioned that the difficulty in predicting cash availability is related to the complexity of the in-and-out cash flow, and the interdependencies among multiple projects. The cash inflows for a contractor results from a progress payment received from the client and outflows to project operational expenses such as materials, labor, equipment, and subcontractors payments. The contractor relies on cash inflows from one project to finance others project. This practice is usually adopted when a significant difference, resulted from retainage, delay in client payment, and credit arrangements with suppliers, between the project's expenses and owner payment, exists (Park et al., 2005).

Financial stability in terms of cash flow has time and cost implications in construction projects. Client delay in payment may cause a stoppage of site work, which means 
dropping the daily productivity to zero (Mohammed et al., 2014). Sweis et al., (2008) found that financial difficulties are the first and most frequent causes of delay in building projects in Jordan. Similar results were discussed by Odeh and Battaineh (2002). Marzouk and El-Rasas (2014) analyzed delay causes in Egyptian construction projects and found that owner's financial problems and delay in paying for completed work are the top delay causes in a construction project. Al-Kharashi and Skitmore (2009) studied the causes of delays in Saudi Arabian public sector construction projects. They concluded that the owner's lack of finance to complete the work and delay in payment is among the top of delay causes. It is noticeable that the Middle East's construction industry shares the same reasons for a project delay. Financial stability in terms of cash flows is the dominant factor in this regard.

Based on the above facts and the comprehensive literature review on the construction productivity factors discussed in the previous section, it can be concluded that the financial stability research coverage in construction projects is global and the productivity research coverage is local. The author's global context of research is that it represents the general project paradigm, time, cost, and quality. For example, the contractor had a financial problem, which caused the project to be delayed. On the other side, the local research area covers the operational characteristics of the construction activities. For example, delay in payment demotivates the labor and causes the construction activities to be delayed because of reduced productivity. However, the total project duration does not need to be affected.

Furthermore, suppose the global and local research coverages are projected in space. In that case, it is expected that the project stakeholders' financial stability will act as the gravitational force that pulls both research areas together. Hence, it is essential to investigate the financial stability contribution toward the project's successfulness in general and toward the construction productivity in particular.

\section{Methodology}

A quantitative approach was used to identify respondents' perception of the effects of financial stability in cash flows and represented by the delay in payment to their financial performance. The approach was also used to collect data to identify the financial stability factor's rank among the other construction productivity factors. The study focuses on contractors on which their companies are classified as small and medium companies. The Authority of Small and Medium Enterprises Development (Riyada) (2020) in Oman classifies the Small and Medium Enterprises (SMEs) into three categories: Micro, Small, and Medium Enterprises. The Micro enterprises are those employing less than six workers and earns less than R.O. 100,000 annually; Small enterprises are those employing less than 26 workers and earns between R.O. 100,000 and R.O. 500,000 annually; Medium enterprises are those employing less than 100 workers and earns between R.O. 500,000 and R.O. 3,000,000 annually. The total number of registered small and medium enterprises in Oman was 42,698 in 2019 , out of which $33.51 \%$ are located in Muscat (National Center for Statistics and Information (NCSI) 2020). The total number represents all small and medium enterprises including those working in the construction industry. Also, the Ministry of Commerce and Industry in Oman has different companies' classification, which relies on its capital as a classification measure. There are five company registration levels: Fourth, Third, Second, First, and Excellent (Ministry of Commerce and Industry (MOCI) 2020). The capitals for those registration levels are R.O. 24,000 , R.O. 49,000, R.O. 99,000, R.O. 249,000 , and greater than R.O. 250,000, respectively.

One of the main challenges when researching small and medium companies in general and small and medium construction companies, in particular, is communication. Although the statistics about those companies are available to the public, communicating with them is a considerable challenge. The majority does not have a website nor a social media account. However, it is possible to reach out to small and medium construction companies if they are registered in the Oman Tender Board. Oman Tender Board is a public entity established in 1973, and it manages the tendering process for all governmental-related projects above R.O. 300,000 (The General Secretariat of the Tender Board, 2020). Oman Tender Board requests all companies to register their companies in the tender board first to be eligible to bid for a project. The tender board also disclose the registered companies' information (i.e., the company's name and telephone number) to the public through its "Registered Companies" database. Therefore, the registered small and medium construction companies registered in Oman Tender Board are considered in this study.

\section{The questionnaire survey}

The questionnaire survey adopted in this study covers two parts besides the demographic information. The first part investigates the contractors' perception of the effect of delay in payment on their financial performance. The second part explores the relative importance of the productivity factors within small and medium construction companies. The rationale behind incorporating both parts in one questionnaire survey is to expose the respondents to the expected effects of the delay in payments on their financial performance and to map the importance of this dimension when considered as a construction productivity factor among the other factors. Table 1 shows both questionnaire survey 
Table 1 Questionnaire survey dimensions, attributes, and scales used

\begin{tabular}{|c|c|c|}
\hline No. & General expected effects of the delay in payments to the contractors financial performance & Scale \\
\hline \multicolumn{3}{|c|}{ Part 1} \\
\hline 1 & Delay in the project payments delays labors wage payments & 5: Strongly Agree \\
\hline 2 & Delay in payment hinders the contractor's labors incentive program & 4: Agree \\
\hline 3 & $\begin{array}{l}\text { Delay in payment affects the amount of the line of credits provided by the materials suppliers or the } \\
\text { financial institutes }\end{array}$ & 3: Neutral \\
\hline 4 & Delay in payment affects the contractor's equipment ownership and operation capabilities & 2: Disagree \\
\hline 5 & Delay in payment affects the contractor's materials supplying capabilities & 1: Strongly Disagree \\
\hline 6 & Delay in payment in one of the projects affects the forecasted cash flow of other projects & \\
\hline 7 & Delay in payment affects the financing cost of the project & \\
\hline 8 & Delay in payment affects the forecasted profit margin & \\
\hline 9 & Delay in payment may erode the contractor's reserve fund & \\
\hline 10 & Delay in payment affects the contractor's financial reliability in the market & \\
\hline 11 & Delay in payment in general critically affects the project successfulness & \\
\hline No. & Productivity factors & Scale \\
\hline \multicolumn{3}{|c|}{ Part 2} \\
\hline 1 & Delay in payment & 5: Extreme effect \\
\hline 2 & Construction method & 4: Substantial effect \\
\hline 3 & Unrealistic time and cost estimate & 3: Moderate effect \\
\hline 4 & Work supervision & 2: Minor effect \\
\hline 5 & $\begin{array}{l}\text { Effectiveness of communication protocol (i.e., clarity of instructions, delay in in responding to } \\
\text { Request for Information (RFI)) }\end{array}$ & 1: No effect \\
\hline 6 & Incomplete drawings or drawings omission & \\
\hline 7 & Overcrowding & \\
\hline 8 & Lack of material & \\
\hline 9 & Lack of proper material handling and storage & \\
\hline 10 & Lack of tools and equipment & \\
\hline 11 & Accidents & \\
\hline 12 & Change orders & \\
\hline 13 & Inspection delay & \\
\hline 14 & Workers absenteeism and turnover & \\
\hline 15 & Poor site conditions and management & \\
\hline 16 & Site accessibility & \\
\hline 17 & Planning and work flow & \\
\hline 18 & Labors skills and experiences & \\
\hline 19 & Weather effect & \\
\hline 20 & Project specifications & \\
\hline 21 & Rework & \\
\hline
\end{tabular}

parts, each associated with its accompanying attributes. The selected attributes for both parts stems from the comprehensive literature review conducted in Sect. 2 and 3. Not all of the productivity factors previously studied are incorporated herein, duplicates- and redundant-considered factors by the authors were removed. For example, it is known that delay in payment demotivates the labors, and hence productivity will be affected; therefore, only the sources of demotivation were considered.

Two scales were used in each dimension; the first used five points Likert scale (5: Strongly Agree, 4: Agree, 3:
Neutral, 2: Disagree, 1: Strongly Disagree). Similarly, the second dimension used five points scale. However, different points representations were used (5: Extreme Effect, 4: Substantial Effect, 3: Moderate Effect, 2: Minor Effect, 1: No Effect). Basic statistical measures like mean, standard deviation, and standard error of the mean will be used to analyze the first dimension. The Relative Importance Index (RII) measure will be used to analyze the second dimension. The RII is calculated using the following equation: 
$R I I_{k}(\%)=\frac{5(n 5)+4(n 4)+3(n 3)+2(n 2)+n 1}{5(n 1+n 2+n 3+n 4+n 5)}$,

where $R I I_{k}$ is the relative importance of factor $k$, and $n_{1}$, $n_{2}, n_{3}, n_{4}$, and $n_{5}$ is the respondents' number in each Likert scale point.

Procedures and formulas used to identify the representative sample of the population is similar in most researches. First, the returned sample size $\left(n_{0}\right)$ is calculated using the following Cochran's sample size formula:

$n_{0}=\frac{t^{2} * s^{2}}{d^{2}}$,

where $n_{0}$ is the returned sample size of the population, $t$ is the statistic value of the selected alpha level, $s$ is the estimate of the standard deviation, and $d$ is the acceptable margin of error for mean.

The alpha level of $2.5 \%$ for each tail will result in a confidence level of $95 \%$ with a statistic value equals 1.96 . The standard deviation estimate $(\sigma)$ is calculated by dividing the inclusive range of the scale, five by four which is the number of standard deviations that include all possible values in the range. The acceptable margin of error for the mean $(\mu)$ in this study is calculated by multiplying the scale point range five by the acceptable margin of error (3\% proposed in the study). The total number of the returned sample size is 267 .

As mentioned previously, the small and medium construction companies registered in Oman Tender Board will be studied. Oman Tender Board disclose all registered companies to the public through their database. "Construction and Maintenance" was selected in the category search field, "Building Construction" in the subcategory search field and "Small and Medium Enterprises (SME)" in the company type search filed. The total number of small and medium construction companies registered was found to be equal to 207. The representative sample size () in this case is equal to 119 and calculated using the following equation (refer to Bartlett et al. (2001) for more information on the representative sample size calculations):

$n=\frac{n_{0}}{1+\frac{n}{\text { Population }}}$.

\section{Discussion of results}

The small and medium construction companies were contacted using the communication info provided by Oman Tender Board database. Two hundred seven companies were targeted in the study, and the representative sample size was 119. All 207 companies were outreached using a phone call, and a brief research description was introduced. A "Google
Form" version of the survey was sent to the participants after receiving their acceptance from participating. The collection data process extended from November 2020 to March 2021. The total number of received responses was 65 , representing $54.6 \%$ of the targeted sample size $(n=119)$.

Figure 1 shows the demographic information of the participants. Omanis represented the majority of the received responses, and males represented $86 \%$ of the total responses. $51 \%$ of the total respondents' ages ranged between 25 and 35 years, and $20 \%$ were above 46 . A good level of education was recorded; hence $61 \%$ of the respondents are diploma, $\mathrm{BSc}$, or MSC/MEng degree holders.

The majority of the respondents' job title was a manager, an engineer, and site superintended. Some of the respondents' job title was the company owner, which cannot be considered a job title, and it is believed that they are running the company and are supposed to be called managers. Although the demographic information shows the respondents background, it can also be used to understand the company's work mechanism subjectively. For example, the company owner can be an employee with a job position called a manager and expect to have a salary with incentives. Also, he has well-defined rules and responsibility. However, if the company's manager is someone else, not the owner, and if the company's sense of ownership by the owner overcomes the manager's rules and responsibility and bypasses his authority, it is expected that the company might have managementrelated challenges, author point of view.

The years of experience of respondents centered with 5-15 years. This result is expected since the small and medium construction companies can be considered startups and can evolve to large companies conditioned by their businesses' success. $56 \%$ of the total number of projects performed by the surveyed small and medium construction companies was under ten projects, with total projects worth between 500 and $1000 \mathrm{k}$ R.O.

Figure 2 shows the basic statistics of the collected responses about the generally expected effects of the delay in payments to the contractors' financial performance (part 1 of the survey). The results shown in Fig. 1 were calculated by averaging the collected scores and finding the standard deviation and error for each item. The average value is interpreted as follow; the respondents agree with the statement if it is greater than three and disagree if less than that. The mean for all items is greater than three, which means that respondents' point of views is consistent. The first item in Fig. 2 covers the direct labor cost. The results show that all participants agree that any delay in the project payment will affect the labor wage payment and might affect the project performance.

The second item covers the motivational perspective of the construction laborers in the monetary incentive program. It was found that the majority of the respondents agree that 
Fig. 1 Demographic information of the participants



- Omani = Non-Omani

Gender



- Male - Female

Age

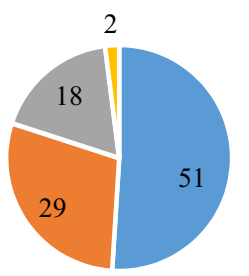

$=25-35=36-46=46-55=>55$

\section{Education}

68



- MSc/MEng

- $\mathrm{BSc}$

- Diploma

- Other (Primary education and high school)
Job title

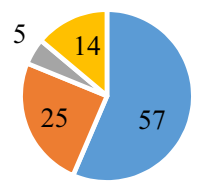

- Manager = Engineer

- Site superintend $\quad$ - Other (Company Owner)

\section{Working experience}



$=5 \quad=5-10 \quad=11-15 \quad=16-20 \quad->20$

Number of ecxuted projects

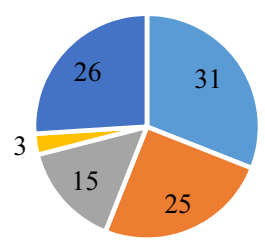

$=1-5 \quad-6-10 \quad-11-15 \quad-16-20 \quad=>20$

Total value of the executed projects (Omani Rials)

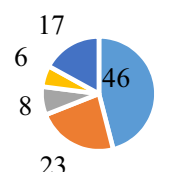

$=<500000 \quad$-500000-1000000

= $1000001-5000000=5000001-10000000$

- >10000000 the labor incentive program can be affected by the delay in project payment. For example, improving safety performance, which is positively correlated with construction productivity, can be achieved by introducing a safety incentive program, and the delay in payment can affect the program.

Using a line of credit to supply construction projects with the required resources is a common practice. The third item in Fig. 2 investigates the possibility of delay in payment, affecting the amount of credit line for the small and medium construction companies. Although the credit line is credited to the contractor company, not the project and since the contractors use cash flowing from multiple projects to the company to pay the debt, however, still all of the respondents accepted that the delay in payment could affect it.

Items four and five in Fig. 2 explore the respondents' perception of how the delay in payment affects the contractor capabilities in terms of operating equipment and supplying materials to the project. Figure 2 shows that all respondents 




Fig. 2 Basic statistics for the general expected effects of the delay in payments to the contractors' financial performance surveyed

agree that their equipment ownership and operations are affected by payment delay. However, the standard deviation of item four shows some variation in the responses. It is believed that the majority of contractors usually rent or lease equipment for the project. Usually, the equipment is rented for a specific time to serve a particular function. Therefore, it was expected that no effect could be imposed on this item by the delay in payment. These results can still be justified because some contractor buys equipment and is required to pay a monthly fee to cover the equipment's financing cost.

Items six to nine in Fig. 2 explore respondents' perception of the effect of delay in payment on the project cash flow, financing cost, forecasted profit margin, and the contractor's reserve funds. All of the respondents supported a direct effect; however, variation in the respondents was noticed in item eight and nine. It is driven by the standard deviation of these items. They were found to be 1.07 and 1.06, respectively. Some of the respondent's results showed that the delay in payment does not necessarily affect the contractor's profit and does not affect the contractor reserve fund.

Part 1 of Table 2 shows the relative importance index (RII) results for the surveyed productivity factors. It is worth mentioning that the first part of the survey was used to explore the respondents' perception of how the delay in payment affects their financial performance. Furthermore, it is used to investigate how the respondents would evaluate the delay in payment as a productivity factor with respect to many other factors. The collected responses show that the delay in payment ranked third out of 21 productivity factors. Although Fig. 2 showed that the delay in payment affects their financial performance; however, the respondents' results in Table 2 show that the delay in payment was not considered the most influencing productivity factor. However, still, it is among the top factors. This result can be correlated with the item number 11 in Fig. 2, "Delay in payment critically affects the project successfulness". It was understood that the delay in payment could affect the project. Still, it does not necessary causes the project to fail. The usual practice by the small and medium construction companies, similarly adopted by large construction companies" is the project payment's front-loading. The contractors tend to ask for large payment in the early stage of the project to avoid any cash flow problem during construction. The extra cash received early in the project can compensate for the delay in payment.

Table 2 shows that the quality and completeness of drawings prepared by the engineer and the management aspect of the small and medium construction companies weigh more than the delay in payment productivity. They were ranked first and second. To compare the rank of delay in payment in the small and medium construction companies context against the large companies, Jarkas et al., (2015) study results were added in Part 2 of Table 2. Jarkas et al., (2015) studied the construction labor determinants in Oman. They 
Table 2 Relative importance index of the productivity factors surveyed

\begin{tabular}{|c|c|c|c|c|}
\hline \multicolumn{3}{|c|}{ Part 1: Current study results } & \multicolumn{2}{|l|}{ Part 2: Jarkas et al., (2015) research results } \\
\hline No. & Productivity factors & RII (\%) & Productivity factors & RII $(\%)$ \\
\hline 1 & Incomplete drawings or drawings omission & 82.15 & Errors and omissions in design & 92.2 \\
\hline 2 & Poor site conditions and management & 82.15 & Change orders during execution & 89.6 \\
\hline 3 & Delay in payment & 81.85 & Delay in responding to requests for information & 87.8 \\
\hline 4 & Lack of tools and equipment & 81.54 & Lack of labor supervision & 86.7 \\
\hline 5 & Workers absenteeism and turnover & 80.92 & Clarity of project specifications & 86.2 \\
\hline 6 & Planning and work flow & 80.62 & Coordination amongst design disciplines & 85.4 \\
\hline 7 & Rework & 80.62 & Working overtime & 84.6 \\
\hline 8 & Lack of materials & 79.38 & Rework & 83.8 \\
\hline 9 & Unrealistic time and cost estimate & 79.08 & Inclement weather & 83.2 \\
\hline 10 & Overcrowding & 78.77 & Labor's physical fatigue & 82.7 \\
\hline 11 & Inspection delay & 78.46 & Unrealistic design schedules imposed on designers & 82.1 \\
\hline 12 & Lack of proper material handling and storage & 78.15 & Labor skills & 81.3 \\
\hline 13 & Labors skills and experiences & 77.54 & Construction method & 80.6 \\
\hline 14 & $\begin{array}{l}\text { Effectiveness of the communication protocol (i.e., clar- } \\
\text { ity of instructions, delay in responding to Request for } \\
\text { Information) }\end{array}$ & 75.38 & $\begin{array}{l}\text { Unrealistic scheduling and expectations of labor perfor- } \\
\text { mance }\end{array}$ & 80.2 \\
\hline 15 & Change orders & 75.38 & Quality of drawings & 78.1 \\
\hline 16 & Weather effect & 74.77 & Unavailability or shortage of materials & 77.6 \\
\hline 17 & Construction method & 73.54 & Low design fees & 76.3 \\
\hline 18 & Site accessibility & 71.69 & Payment delay & 75.8 \\
\hline 19 & Project specifications & 71.08 & Stringent inspection by the engineer & 75.2 \\
\hline 20 & Accidents & 70.46 & Sequencing problems & 74.3 \\
\hline 21 & Work supervision & 68.62 & Labor motivation & 73.9 \\
\hline 22 & & & Inspection delay by the engineer & 72.4 \\
\hline 23 & & & Accidents due to poor site safety & 71.3 \\
\hline 24 & & & Unforeseen ground conditions & 70.2 \\
\hline 25 & & & Congestion and labor interference & 67.9 \\
\hline 26 & & & Incompetent supervisors & 66.3 \\
\hline 27 & & & Site layout & 63.9 \\
\hline 28 & & & Excessive delay in statutory approvals & 62.7 \\
\hline 29 & & & Design complexity & 61.2 \\
\hline 30 & & & Confinement of working space & 57.1 \\
\hline 31 & & & $\begin{array}{l}\text { Ineffective communication between site management and } \\
\text { labor force }\end{array}$ & 55.2 \\
\hline 32 & & & Frequent changes in statutory regulations & 52.6 \\
\hline 33 & & & Crew size and composition & 51.7 \\
\hline
\end{tabular}

surveyed excellent and first grades construction companies registered in Oman Tender Board. The delay in payment was ranked 18 by the large construction companies, which indicates the large companies' good capability to handle monetary issues compared to the small and medium construction companies.

Surprisingly, both studies have the same results regarding the first ranked productivity factor: errors and omissions in design. The large companies, ranked excellent, usually handle large projects and finding errors and omissions in the design are expected since large projects sometimes involve complex structures. However, it is not the same in small projects, which generally include constructing simple design elements. These errors in designs are usually the designer's mistake; however, it affects the construction productivity since work stoppage will be avail repeatedly during the project life.

It can be seen that the delay in payment in the current study is placed before the lack of tools and equipment (item 4) and lack of materials (item 8). These results support the fact that the contractor relies on projects cash flow to purchase materials and provide the required tools, and 
any delay in payment will create a problem in the project supply chain. However, when it comes to large construction companies, the delay in payments is ranked after the unavailability or shortage of materials, which means the delay in payment may not have a significant effect on the project supply chain; hence, the financial capacity of a large company can compensate the delay in payments, author perspective.

Also, the actual time and cost estimate and the delay in payment can affect construction productivity. Down estimate of the time required to accomplish the project tasks will result in extending the time and increasing the project's cost. The contractor will have to extend the working hours of the labors, and such extension may not be considered in the planning stage, which sometimes the paying the labor in full might be delayed. Such scenarios directly affect the labor motivational aspect, and thus, the labor may not show interest to work as planned by the management.

\section{Conclusion}

Construction projects are subjected to many external and internal factors that affect construction productivity. Identifying the relatively importing construction productivity factors helps to better plan and utilize the construction project resources. Based on the comprehensive literature review conducted in this study, the delay in payment was one of the construction productivity factors identified. The previous researches focus was the large construction companies. However, the rank of the relative importance of the delay in payment could be different in the small and medium construction companies. Delay in payment affects the companies' cash flow and could affect their financial stability. The large companies are usually financially stable; however, it is not the case in the small and medium construction companies. The questionnaire survey results distributed to 65 small and medium construction companies registered in Oman Tender Board highlighted that the delay in payment in a project could significantly contribute to its financial performance.

Furthermore, using the relative importance index (RII), the delay in payment was ranked third out of 21 construction productivity factors surveyed. Besides, the study compared the rank of the delay in payment against a result from a previous study. The previous study in Oman the construction productivity using relative importance index calculated from data collected from a questionnaire survey of large construction companies registered Oman Tender Board. The result showed the delay in payment was ranked 18 th out of 33 construction productivity factors surveyed. Therefore, it can be concluded that the effect of delay in payment to financial stability and construction productivity is substantially affecting the small and medium construction companies compared to the large companies.

The future direction of this study is to explore the perception of clients, engineers, and financial institutes' representative who had involved in a project with small and medium construction companies about the financial stability effects on construction projects. This future direction will allow identifying a global understanding of how the delay I payment would affect small and medium construction companies' financial performance.

Funding Not applicable.

\section{Declarations}

Conflict of interest The author declares no conflict of interest.

Open Access This article is licensed under a Creative Commons Attribution 4.0 International License, which permits use, sharing, adaptation, distribution and reproduction in any medium or format, as long as you give appropriate credit to the original author(s) and the source, provide a link to the Creative Commons licence, and indicate if changes were made. The images or other third party material in this article are included in the article's Creative Commons licence, unless indicated otherwise in a credit line to the material. If material is not included in the article's Creative Commons licence and your intended use is not permitted by statutory regulation or exceeds the permitted use, you will need to obtain permission directly from the copyright holder. To view a copy of this licence, visit http://creativecommons.org/licenses/by/4.0/.

\section{References}

Abdul Kadir, M.R., Lee, W.P., Jaafar, M.S., Sapuana, S.M., Ali, .A.A. (2005). Factors affecting construction labour productivity for Malaysian residential projects. Structural Survey, 23(1), 42-54.

Ailabouni, N., Gilado, K., Painting, No (2009). Factors affecting employee productivity in the UAE construction industry. In 25th Annual ARCOM Conference, Nottingham.

Al Balushi, H., Al-Alawi, M., \& Al-Shahri, M. (2020). Modeling, investigating, and quantification of the hot weather effects on construction projects in Oman. The Journal of Engineering Research, 17(2), 89-99.

Al-Abbadi, G.M., Agyekum-Mensah, G. (2019). The effects of motivational factors on construction professionals productivity in Jordan. International Journal of Construction Management, 1-12. https:// doi.org/ 10.1080/15623599.2019.1652951.

Alaghbari, W., Al-Sakkaf, A. A., \& Sultan, B. (2018). Factors affecting construction labour productivity in Yemen. International Journal of Construction Management, 19(1), 79-91.

Alinaitwe, H. M., Mwakali, J. A., \& Hansson, B. (2010). Factors affecting the productivity of building craftsmen-Studies of Uganda. Journal of Civil Engineering and Management, 13(3), 169-176.

Al-Kharashi, A., \& Skitmore, M. (2009). Causes of delays in Saudi Arabian public sector construction projects. Construction Management and Economics, 27(1), 3-23.

Allen, W. A., \& Wood, G. (2006). Defining and achieving financial stability. Journal Finiacial Stability, 2(2), 152-172. 
Almathami, K.Y., Trigunarsyah, B., Coffey, V. (2017). Factors influencing productivity in construction. In The Ninth International Structural Engineering and Construction Conference. Valencia.

Al-Rubaye, Z.R.A. Mahjoob, A.M.R. (2020a). Identify the main factors affecting labor productivity within different organizational structures in the Iraqi construction sector. In: The Fourth Postgraduate Engineering Conference. Ho Chi Minh.

Al-Rubaye, Z. R., \& Mahjoob, A. M. R. (2020b). Using measured mile method to quantify the loss of labor productivity in Iraqi construction site. Asian Journal of Civil Engineering, 21, 1287-1296.

Authority of Small and Medium Enterprises Development (Riyada), "SME Definition," 510 2020. https://riyada.om/en-us/aboutus/ Pages/definesme.aspx.

Bajjou, M. S., \& Chafi, A. (2020). Empirical study of schedule delay in Moroccan construction projects. International Journal of Construction Management, 20, 783-800.

Bartlett, J. E., Kotrlik, J. W., \& Higgins, C. C. (2001). Organizational research: Determining appropriate sample size in survey research. Information Technology, Learning, and Performance Journal, 19(1), 43-50.

Chalhoub, J., \& Ayer, S. K. (2018). Using Mixed Reality for electrical construction design communication. Automation in Construction, $86,1-10$.

Chih, Y.-Y., Kiazad, K., Cheng, D., Lajom, J. A. L., \& Restubog, S. L. (2017). Feeling positive and productive: Role of supervisorworker relationship in predicting construction workers' performance in the Philippines. Journal of Construction Engineering and Management, 143(8), 04017049.

Doloi, H. (2008). Application of AHP in improving construction productivity from a management perspective. Construction Management and Economics, 26(8), 841-854.

El-Gohary, K. M., \& Aziz, R. F. (2014). Factors influencing construction labor producitivity in Egypt. Journal of Management in Engineering, 30(1), 1-19.

El-khalek, H. A., Aziz, R. F., \& Morgan, E. S. (2019). Identification of construction subcontractor prequalification evaluation criteria and their impact on project success. Alexandria Engineering Journal, 58(1), 217-223.

Enshaasi, A. (2014). Constraints to plestininan construction craftsmen productivity. In: The 22nd Annual Conference of the International Group for Lean Construction, Oslo

Evanov, B. A., Rohlman, D. S., Strickland, J. R., \& Dale, A. M. (2020). Influence of work organization and work environmenton missed work, productivity, and use of pain medicationsamong construction apprentices. American Journal of Industrial Medicine, 63(3), 269-276.

Florez, L., Armstrong, P., \& Cortissoz, J. C. (2020). Does compatibility of personality affect productivity? Exploratory study with construction crew. Journal of Management in Engineering, 36(5), 04020049.

Ghoddousi, P., Poorafshar, O., Chileshe, N., Hosseini, M.R. (2015). Labour productivity in Iranian construction projects- Perceptions of chief executive officers. International Journal of Productivity and Performance Management, 64(6), 811-830.

Goodrum, P. M., Zhai, D., \& Yasin, M. F. (2009). Relationship between changes in material technology and construction productivity. Journal of Construction Engineering and Management, 135(4), 278-287.

Halligan, D. W., Demsetz, L. A., \& Brown, J. D. (1994). Actionresponse model and loss of productivity in construction. Journal of Construction Engineering and Management, 120(1), 47-64.

Hasan, A., Baroudi, B., Elmualim, A., Rameezdeen, R. (2018) Factors affecting construction productivity: A 30 year systematic review. Engineering Construction and Architectural Management, 25(7), 916-937.
Hiyassat, M. A., Hiyari, M. A., \& Sweis, G. J. (2016). Factors affecting construction labour productivity: a case study of Jordan. International Journal of Construction Management, 16(2), 138-149.

Huang, W.-H., Tserng, H. P., Jaselskis, E. J., \& Lee, S.-Y. (2014). Dynamic threshold cash flow-based structural model for contractor financial prequalification. Journal of Construction Engineering and Management, 140(10), 04014047.

Jamshidi, S. F., \& Hatefi, S. M. (2016). Identification of reasons for claims of contractors in D-B-B contracts and evaluation by multicriteria decision-making models (AHP). International Journal of Optimization in Civil Engineering, 6(4), 559-568.

Jarkas, A. M., Radosavljevic, M., Wuyi, L. (2014) Prominent demotivational factors influencing the productivity of construction project managers in Qatar. International Journal of Productivity and Performance Management, 63(8), 1070-1090.

Jarkas, A. M. (2015). Factors influencing labour productivity in Bahrain's construction industry. International Journal of Construction Management, 15(1), 94-108.

Jarkas, A., Al Balushi, R. A., \& Raveendranth, P. K. (2015). Determinants of construction labour productivity in Oman. International Journal of Construction Management, 15(4), 332-334.

Jarkas, A. M., \& Bitar, C. G. (2012). Factors affecting construction labor productivity in Kuwait. Journal of Construction Engineering and Management, 138(7), 811-820.

Jarkas, A. M., Kadri, C. Y., \& Younes, J. H. (2012). A survey of factors influencing the productivity of construction operatives in the State of Qatar. International Journal of Construction Management, 12(3), 1-23.

Jarkas, A. M., \& Radosavljevic, M. (2013). Motivational factors impacting the productivity of construction master craftsmen in Kuwait. Journal of Management in Engineering, 29(4), 446-454.

Kaveh, A., \& Vazirinia, Y. (2020). Chaotic vibrating particles system for resource-constrained project scheduling problem. Scientia Iranica, 27(4), 1826-1842.

Khaleel, T., Nasser, Y. (2017). Identification and analysis of factors affecting labour productivity in Iraq. In The 3rd International Conference on Buildings, Construction and Environmental Engineering, Sharm el-Shiekh

Kishore, V., Abraham, D. M., \& Sinfield, J. V. (2011). Portfolio cash assessment using fuzzy systems theory. Journal of Construction Engineering and Management, 137(5), 333-343.

Mahamid, I. (2013). Contractors perspective toward factors affecting labor productivity in building construction. Engineering, Construction, Architectural Management, 20(5), 446-460.

Marzouk, M. M., \& El-Rasas, T. I. (2014). Analyzing delay causes in Egyptian construction projects. Journal of Advanced Research, $5(1), 49-55$.

Ministry of Commerce and Industry (MOCI). (2020). "FAQ," 510 2020. https://www.moci.gov.om/wps/portal/MoCI/MOCI\% 20home/About/FAQ/!ut/p/a0/04_Sj9CPykssy0xPLMnMz0v MAfGjzOL9HR1NPN1NjDz9nQ3NDRyNTII8A0McjQ1cjfSD E4v0C7IdFQFLv2pA/.

Mohammed, A. M., Alnuaimi, A., \& Al Tobi, S. (2014). Contractual implications of cash flow on owner and contractor in villa construction projects. International Journal of Research in Engineering and Technology, 3(4), 442-447.

Naoum, S.G. (2016). Factors influencing labor productivity on construction sites-A state-of-the-art literature review. International Journal of Productivity and Performance Management, 65(3), 401-421.

National Center for Statistics and Information (NCSI). (2020). Small and Medium Enterprise 510 2020. https://data.gov.om/eopqlmg/ small-and-medium-enterprise. 
OCED. (2001). Measuring productivity - measurement of aggregate and industrial-level productivity growth - OCED manual. Paris: Organization for Economic Cooperation and Developemnt.

Odeh, A. M., \& Battaineh, H. T. (2002). Causes of construction delay: Traditional contracts. International Journal of Project Management, 20(1), 67-73.

Park, H.-S. (2006). Conceptual framework of construction productivity estimation. KSCE Journal of Civil Engineering, 10(5), 311-318.

Park, H. K., Han, S. H., \& Russel, J. S. (2005). Cash Flow Forecasting Model for General Contractors Using Moving Weights of Cost Categories. Journal of Management in Engineering, 21(4), 164-172.

Plebankiewicz, E. (2009). Contractor Prequlaification model using fuzzy sets. Journal of Civil Engineering and Management, 15(4), 377-385.

Rad, K. G., \& Kim, S.-Y. (2018). Factors affecting construction labor productivity: Iran case study. Iranian Journal of Science and Technology, Transactions of Civil Engineering, 42(2), 165-180.

Seo, H.-C., Lee, Y.-S., \& Jee, N.-Y. (2015). Analyzing safety behaviors of temporary construction workers usingstructural equation modeling. Safety Science, 77, 160-168.

Shan, Y., Goodrum, P. M., Zhai, D., \& Haas, C. (2011). The impact of management practices on mechanical construction productivity. Construction Management and Economics, 29(3), 305-316.

Shurrab, M. (2018). Evaluating the effect of motivational dimensions on the construction project managers in Jordan. Engineering, Construction and Architectural Management, 25(3), 412-424.

Sweis, G., Sweis, R., Abu Hammad, A., \& Shboul, A. (2008). Delays in construction projects: The case of Jordan. International Journal of Porject Management, 26(6), 665-674.
Sweis, R. J., Bisharat, S. M., Bisharat, L., \& Sweis, G. (2014). Factors affecting contractor performance on public construction projects. Life Science Journal, 11(4s), 28-39.

Taiwo, A. S. (2010). The influence of work environment on workers productivity: A case of selected oil and gas industry in Lagos, Nigeria. African Journal of Business Management, 4(3), 299-307.

The General Secretariat of the Tender Board. (2020). The General Secretariat of the Tender Board," 510 2020. https://etendering. tenderboard.gov.om/product/DefineFAQ?callValue=pubDashLin kContent.

United State Department of Labor. (2020). Long work hours, extended or irregular shifts, and worker fatigue 159 2020. https://www. osha.gov/SLTC/workerfatigue/hazards.html.

Volkov, A., Shilova, L. (2016). Principles of formation of stability of construction projects. In XXV Polish - Russian - Slovak Seminar "Theoretical Foundation of Civil Engineering". Zilina.

Wong, J. H., Rashidi, A., Arashpour, M.(2020). Evaluating the impact of building information modeling on the labor productivity of construction projects in Malaysia. Buildings, 10(4)

Publisher's Note Springer Nature remains neutral with regard to jurisdictional claims in published maps and institutional affiliations. 